\title{
Assessment of the ecological status of the shallow Lake Neor (Iran) using a macroinvertebrate community structure
}

\author{
R. M. Nadushan ${ }^{1}$, H. Emadi ${ }^{1}$, M. R. Fatemi ${ }^{2}$ \& M. Samanpajuh ${ }^{1}$ \\ ${ }^{I}$ Department of Fisheries, Faculty of Marine Science and Technology, \\ North Branch of Tehran, Islamic Azad University, Iran \\ ${ }^{2}$ Department of Marine Biology, \\ Faculty of Marine Science and Technology, \\ Science and Research Branch, Islamic Azad University, Iran
}

\begin{abstract}
Macroinvertebrates play a key role in freshwater lentic and lotic ecosystems. Lake Neor, located in the northwest of Iran $\left(37^{\circ} 55^{\prime}\right.$ to $\left.38^{\circ} 1^{\prime} 45\right), 2700 \mathrm{~m}$ above sea level, is one of the lakes with little information available regarding the limnological data. Therefore, the present study was planned and conducted during a period of one year focusing on macroinvertebrate fauna and assemblage. Sampling was done monthly at four sites from August 2008 to July 2009. Altogether, a total of 11 species belonging to three phyla, seven classes, 10 orders and 10 families were identified, indicating a low diversity. From these species, eight are recorded for the first time from this lake and from the country, including Pisidium supinum, Fossaria humilis, Stagnicola catascopium, Quistadrilus multisetosus, Stylodrilus herngianus, Mooreobdella fervida, Podura aquatica, Dasycorixa hybrida. From these species, Gammarus fasciatus, Pisidium supinum and Quistadrilus multisetosus were dominant, constituting $49 \%, 43 \%$ and $5 \%$ of the total benthic fauna respectively. Two predominant species, Gammarus fasciatus and Pisidium supinum, are indicator species that are sensitive to eutrophic conditions, reflecting the oligo-mesotrophic character of the lake. Dissolved oxygen, temperature, TOM and habitat homogeneity seemed to be the main environmental factors affecting the community structure of macroinvertebrate fauna in this lake. At present, in this shallow water body
\end{abstract}


with an average depth of 3 and a maximum of 5 meters, the annual water level fluctuation is around 1 to 2 meters during the period of using water for agricultural purposes. These annually high water level fluctuations would result in an increase in nutrient recycling and nutrient release to the water column, which in turn might affect the trophic status of the lake. Hence, the present situation of the lake, mainly its trophic regime, clearly shows the need for developing a management and monitoring plan.

Keywords: shallow lake, macroinvertebrates, assessment, trophic status, Lake Neor.

\section{Introduction}

Macroinvertebrates play a key role in freshwater ecosystems in linking primary production, allochthonous input and top predators in freshwater ecosystems. They are usually diverse, are represented by many phyla and have different requirements for feeding, growth and reproduction. This often results in an extremely heterogeneous distribution of the macroinvertebrate community [1]. Composition and abundance of zoobenthos depend on multiple environmental factors (physical or/and chemical) and substratum type [2, 3]. Detritivores prevail in habitats rich in organic matter, e.g. in the vicinity of plants [4]. Bare sand is inhabited by psammophiles [3,4], while habitats experiencing oxygen deficiencies are dominated by organisms resistant to hypoxia [5]. Plants are extremely important for composition and abundance of bottom fauna, as well as for epiphytic and mining organisms, providing a food source and protection against predators and excessive water movements. Use of macroinvertebrates as biotic indicators has been applied mostly to deep lake ecosystems and may provide a reliable indicator of eutrophication. According to Wetzel [1], their use in shallow lakes is not clear.

Lake Neor is an ancient shallow lake ecosystem situated in a topographically diverse landscape on the western flank of the Baghrudagh mountain range, NW Iran. Lake Neor formed tectonically during the late Eocene epoch. The basin has a cold mountainous climate with an annual precipitation $400 \mathrm{~mm}$. Due to high latitude (2500-3200 meter above sea level), high precipitation, physico-chemical processes, slopes lower than $35 \%$, erosion and sediment transfer has been high (430 ton. $\mathrm{ha}^{-1}$.year ${ }^{-1}$ ) and during recent decades sediment deposit and irrigation has impacted the lake's trophic state.

Neor Lake is a growing place for rainbow trout introduced to the lake many years ago for sport and commercial fishing; therefore, every year a few thousand fingerlings are released into the lake to support this fishery. These fishes are fed on the bottom dwelling Gammarus fasciatus and have a very rapid growth and very peculiar characteristics with pink flesh. The natural surroundings of the lake are also the habitat of birds, such as ruddy shelduck and migrant swallows and are a famous resort for many people who come to the lake during the summer, but the lake lacks an ecological and tourisms management plan to ensure its sustainability. 


\section{Materials and methods}

Lake Neor, NW Iran $\left(48^{\prime} \mathrm{E}, 38^{\prime} \mathrm{N}\right)$ is a shallow water body with a mean depth of 3 and a maximum of $5.5 \mathrm{~m}$. It occupies an area of 420 acre and is $2700 \mathrm{~m}$ above sea level. There are 13 permanent and seasonal springs originating from the surrounding heights and a few underground springs within the lake. Four

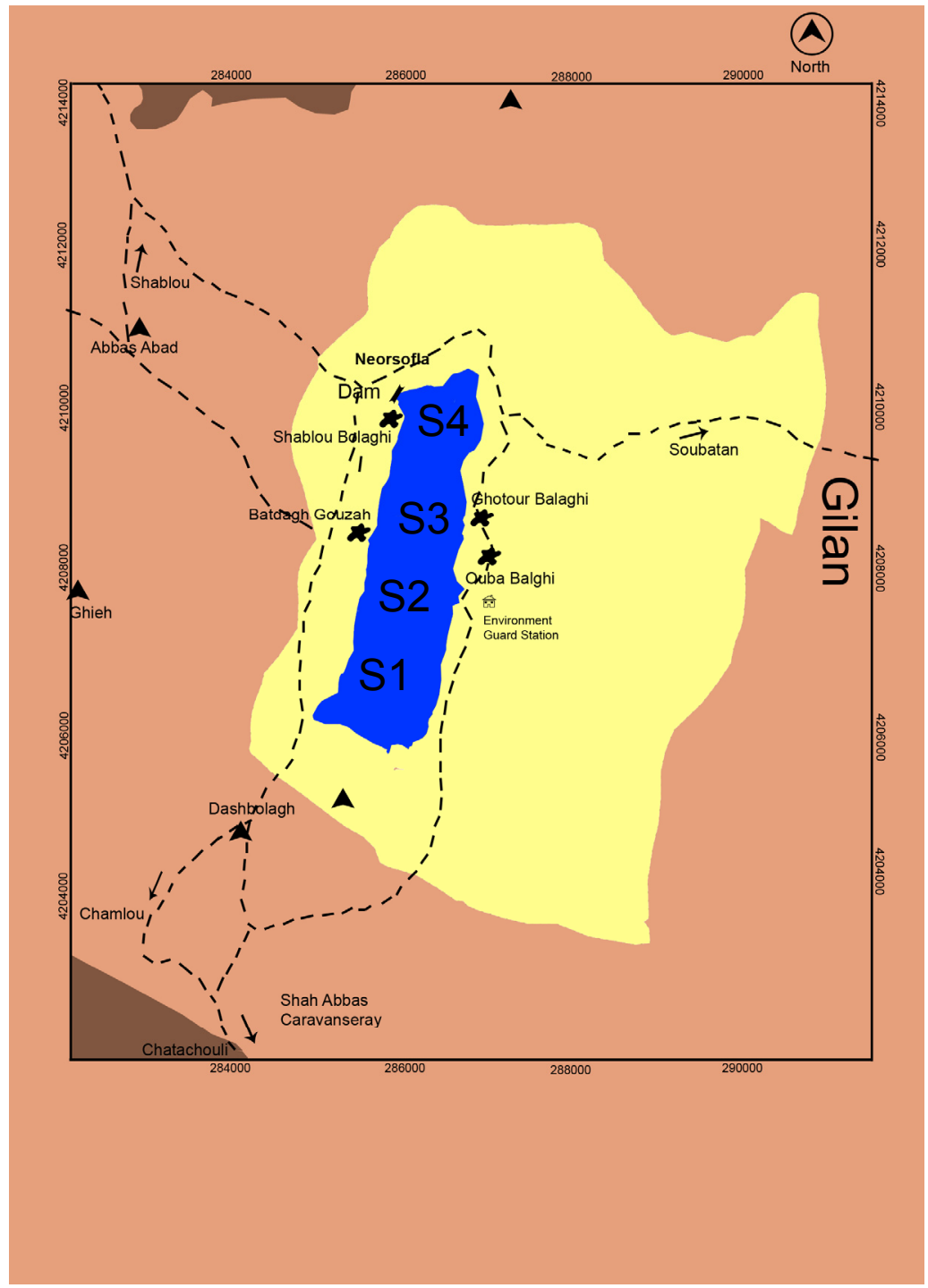

Figure 1: Schematic map of Lake Neor and location of sampling sites (not to scale). 
sampling sites were surveyed in Lake Neor. All sites represented the sublittoral (S1 and S4) and the profundal zone (S3, S4). The littoral zone of Lake Neor is subjected to seasonal fluctuations and the water level falls to approximately 1-2 $\mathrm{m}$ below the mean level between the winter and summer periods because of irrigation. Regarding this impact, this research focused on the sublittoral and profundal benthos.

Monthly samples (in triplicate) were taken from August 2008 to July 2009 using an Ekman grab sampler $\left(225 \mathrm{~cm}^{2}\right)$. All samples were sieved (mesh size 0.5 $\mathrm{mm}$ ) and preserved in $10 \%$ formalin. Macroinvertebrates were sorted to the lowest practicable taxonomic level. Water samples were collected using a HydroBios water sampler (2 litre capacity) from the same stations at the surface and bottom zone ( $0.5 \mathrm{~m}$ above bottom). Temperature, $\mathrm{pH}$ and $\mathrm{DO}$ were measured using a WTW meter. Water transparency was estimated with a Secchi disk. Organic matter content in sediments and grain size was determined by heating $1 \mathrm{~g}$ of dried $\left(24 \mathrm{~h}\right.$ at $\left.100^{\circ} \mathrm{C}\right)$ sediments at $550{ }^{\circ} \mathrm{C}$ for $2 \mathrm{~h}$.

\section{Results}

Variations, of environmental variables among sites and dates indicate some distinct temporal and spatial trends. The surface water temperatures varied from $0^{\circ} \mathrm{C}$ in January to $17.7^{\circ} \mathrm{C}$ in August and bottom temperatures followed the same variation (i.e. from $4^{\circ} \mathrm{C}$ in January to $16.8^{\circ} \mathrm{C}$ in August). A weak thermal stratification was noticed from December; the ice period started in January and continued through April, while the water mixing began early in May (sampling in March and April was done after breaking the ice cover) (Figure 2(a)). The lake's mixing regime is continuous cold polymictic.

The dissolved oxygen in surface waters fluctuates between $8.6 \mathrm{mg} \mathrm{l}-1$ and $11.23 \mathrm{mg} \mathrm{l}-1$, and in the bottom waters between $7.9 \mathrm{mg} \mathrm{l}-1$ and $8.75 \mathrm{mg} \mathrm{l}-1$; appearing DO values were always at saturation level throughout the period of no ice cover (Figure 2(b)).

Secchi-disk transparency varied between 0.25 and $0.48 \mathrm{~m}$. The highest values may be related to the low phytoplankton biomass, while there was low seasonal variability throughout the year (Figure 2(c)).

Sediments in all sampling stations were fine with a diameter of less than 0.06 $\mathrm{mm}$. Organic content of sediments is shown in Figure 3.

Altogether 11 species belonging to 3 phyla, 7 classes, 10 orders and 10 families were identified from quantitative samples. Adult Dasycorixa hybrida and Podura aquatica were observed in springs inlets and sampling stations under ice respectively.

According to abundance Gammarus fasciatus, Pisidium supinum and Quistadrilus multisetosus were predominant and they contributed $49 \%, 43 \%$ and $5 \%$ of total density (their relative abundance were $49 \%, 43 \%$ and $5 \%$ ). Relative abundance of Stylodrilus heringianus was 1\% while the overall abundances of other species were low. Densities of Oligochaete species were maximal during the late spring and of other species were in late summer and early autumn, all with one peak in seasonal pattern. 
(a)

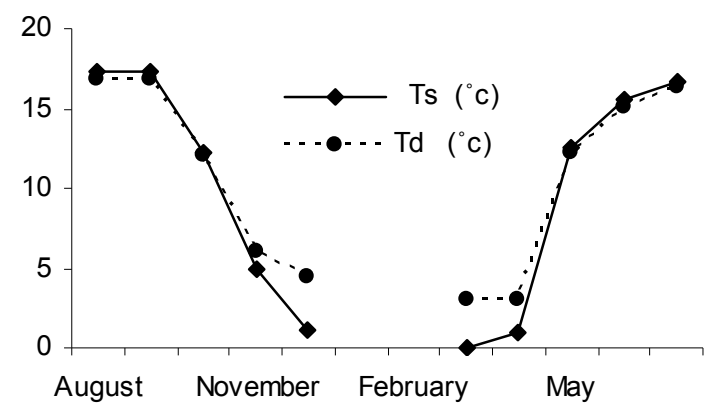

(b)

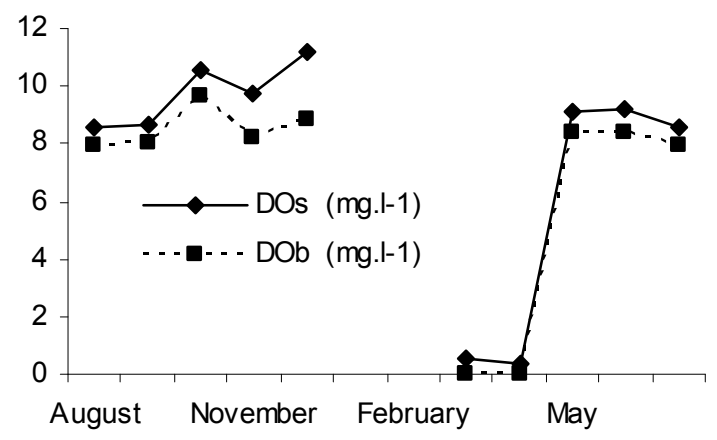

(c)

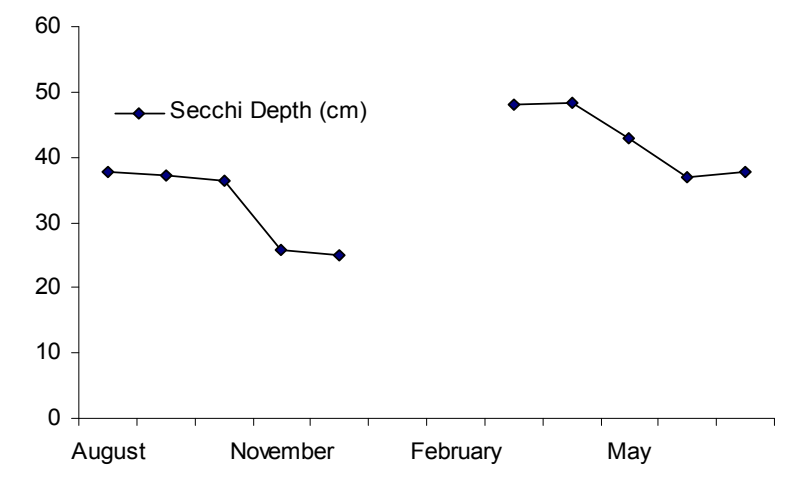

Figure 2: Monthly variation of temperature, dissolved oxygen (s: surface and d: depth near bottom) and Secchi depth of Lake Neor - August 2008 to July 2009. 


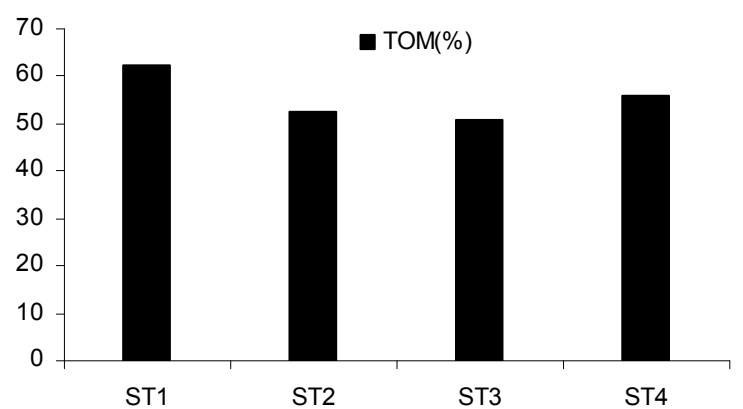

Figure 3: Sediment organic content of Lake Neor at the four sampling stations.

Table 1: Taxonomic composition and classification of the macroinvertebrates of Lake Neor - August 2008 to July 2009.

\begin{tabular}{|c|c|c|c|c|c|}
\hline Phylum & Class & Order & Family & Genus & Species \\
\hline \multirow[t]{4}{*}{ Arthropoda } & Malacostraca & Amphipoda & Gammaridae & Gammarus & G. fasciatus \\
\hline & Insecta & Diptera & Chironomidae & Chironomus & Chironomus sp. \\
\hline & & Hemiptera & Corixidae & Dasycorixa & D. hybrida \\
\hline & Entognatha & Collembola & Poduridae & Podura & P. aquatic \\
\hline \multirow[t]{3}{*}{ Annelida } & Oligochaeta & Tubificida & Tubificidae & Quistadrilus & Q. multisetosus \\
\hline & & Lumbriculida & Lumbriculidae & Stylodrilus & S. heringianus \\
\hline & Hirudinea & Arhynchobdellida & Erpobdellidae & Mooreobdella & M.fervida \\
\hline \multirow[t]{4}{*}{ Mollusca } & Gastropoda & Pulmonata & Planorbidae & Planorbis & P. carinatus \\
\hline & & Basommatophora & Lymnaeidae & Stagnicola & S. catascopium \\
\hline & & & & Fossaria & F.humilis \\
\hline & Bivalvia & Veneroida & Sphaeriidae & Pisidium & P.supinum \\
\hline
\end{tabular}

Stagnicola catascopium and Fossaria humilis were not found in samples from station 1 during the study period. Other taxa were observed at all months and all stations. Moreover, no differences in abundance and taxonomic composition (number of taxa) were found between months and the stations in Lake Neor (ANOVA, $\mathrm{P}>0.05$ ). 


\section{Discussion}

Lake Neor, located in northwest of Iran, $2700 \mathrm{~m}$ above sea level is ice-covered 5 months and during ice free months, circulation is continuous, so this lake is a Continuous Cold Polymictic. In this study it was shown that benthic macrofauna of Lake Neor was dominated by Gammarus fasciatus and Pisidium supinum. Quistadrilus multisetosus and Stylodrilus heringianus had 5\% and 1\% of total density respectively and other organisms were less common.

Gammarus fasciatus is known to be particular abundant in shallow well oxygenated areas, survives well at water temperatures around $10-15^{\circ} \mathrm{C}$, generally a dominant species in water bodies with thick macrophyte beds and organic rich sediments [6] and common in Oligo-mesotrophic conditions.

(a)

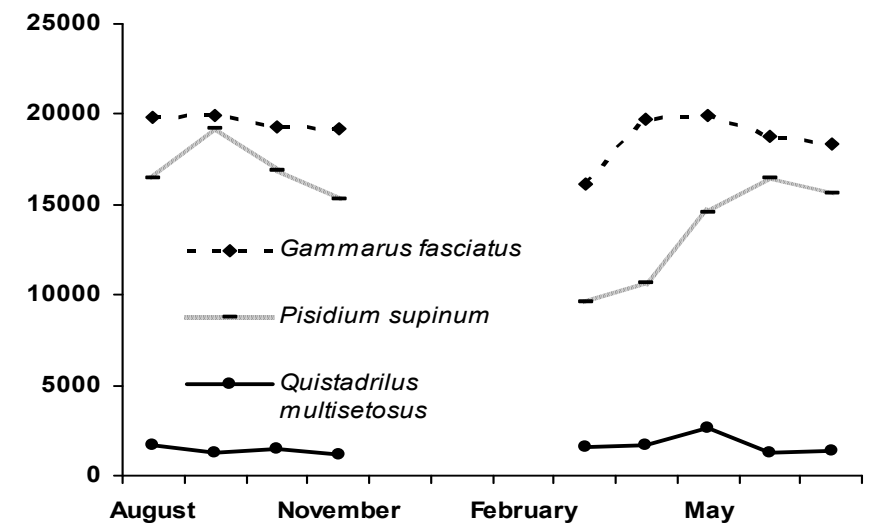

(b)

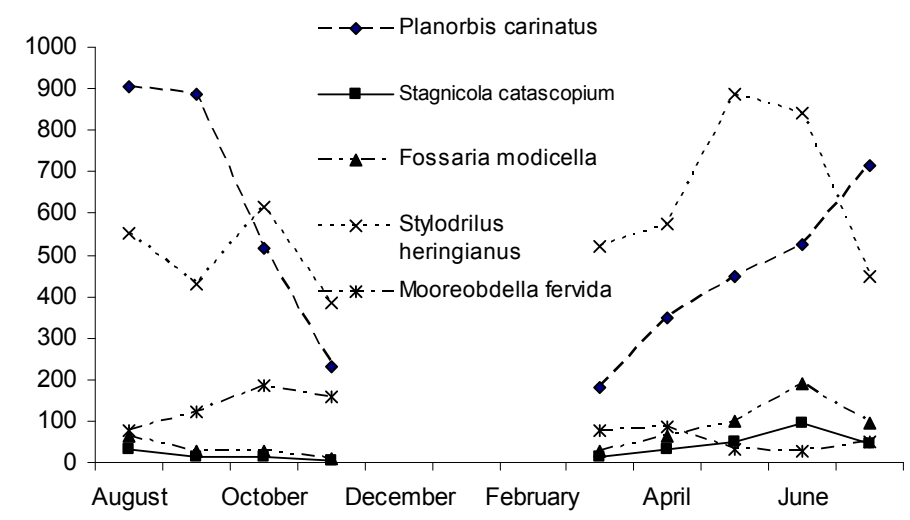

Figure 4: Monthly population densities of the most abundant benthic species in Lake Neor - August 2008 to July 2009. 
P. supinum is second dominant species reflecting Oligo-mesotrophic state of Lake Neor since it is known to be very sensitive to eutrophication [7]. (It is a good indicator of water quality since it is very sensitive to eutrophication.). It filters suspended material from the water column but can directly ingest deposits from the sediments as well, so it can reach to high densities in organic rich sediments $[8,9]$. The dominant species among Oligochaetes was Quistadrilus multisetosus in Lake Neor. It exists in settings with underground springs and macrophyte beds [10]. Underground springs are scattered all over in Lake Neor. Stylodrilus heringianus is another characteristic species indicating oligotrophy, usually with low abundance [11]. Planorbis carinatus was the dominant species among Gastropods in Lake Neor, especially in shoreline. This snail is known as common inhabitant of calm, clear water with rich vegetation, feed on dying or dead water plants and algae and an indicator of oligotrophic condition.

From the present work it is clear that taxonomic composition of the zoobenthos of the Lake Neor is typical for an oligo-mesotrophic shallow water body. It is dominated by detritivorous organisms living in shallow well oxygenated waters, such as Gammarus fasciatus and Pisidium supinum and Planorbis carinatus. Two other dominant species Quistadrilus multisetosus and Stylodrilus heringianus are pelophilous inhabitant of profundal zone of eutrophic and oligotrophic lakes respectively. On the other hand the total zoobenthos density in our study, especially for two dominant species is high and comparable with eutrophic lakes (Figure 4(a)). It was demonstrated that macrophytes increase habitat heterogeneity [3, 12], improve food conditions, stabilize bottom sediments and provide protection against wave action [3], and their presence stimulates development of diverse and abundant bottom fauna [2, 13, 14]. It seems organic-rich sediments in Lake Neor have very high quantity and quality of food especially in vicinity of littoral plants for benthic fauna (Figure 3). However water level fluctuations have reduced the diversity, or altered the composition of littoral habitats in this lake. Therefore low richness in Lake Neor may be a result of the very variable environmental conditions such as annual temporary exposure of its phytolittoral parts to air.

\section{Conclusions}

In this study, we could show the trophic status of the lake. Suitable physical characteristics, water turnover, dissolved oxygen, low depth have favoured in a high density of Gammarus fasciatus living in an oligo-mesotrophic condition. At present biological integrity of this lake in terms of species richness (and productivity) is relatively intact, just annual water level fluctuations (for irrigation) would result in phytolittoral habitats become inaccessible for benthic invertebrates especially with receding lake water level and an increase in organic matter in vicinity of these plants. This continuous stressful condition may result in an increase in TOM, nutrient recycling and nutrient releasing to the water column which in turn might affect the trophic status of the lake. Hence the present situation of the lake mainly its trophic regime, clearly shows need for developing a management and monitoring plan. 


\section{References}

[1] Wetzel, R. G.; Limnology, Lake and river ecosystems. San Diego, USA: Academic Press. pp. 665-710, 2001.

[2] Heino, J, Lentic macroinvertebrate assemblage structure along gradients in spatial heterogeneity, habitat size and water chemistry, Hydrobiologia. (418), pp. 229-242, 2000.

[3] Tolonen, K.T., Hämäläinen, H., Holopainen, I.J. and Karjalainen, J., Influences of habitat type and environmental variables on littoral macroinvertebrate communities in a large lake system. Arch Hydrobiol, (152), pp. 39-67, 2001.

[4] Timm, T., Seire, A., Pall, P., Half a century of oligochaete research in Estonian running waters. Hydrobiologia (463), pp. 223-234, 2001.

[5] Brodersen, K.P., Pedersen, O., Lindegaard, C., Hamburger, K., Chironomids (Diptera) and oxy-regulatory capacity: an experimental approach to paleolimnological interpretation. Limnol. Oceanogr. (49), pp. 1549-1559, 2004.

[6] Risnoveanu, G., \& Vadineanu, A Long-term functional changes within the Oligochaeta communities within the Danube River Delta, Romania. Hydrobiologia, (506/ 509), 399-405, 2003.

[7] Reckendorfer, W., Baranyi, C. Funk, A. \& Schiemer, F., Floodplain restoration by reinforcing hydrological connectivity: expected effects on aquatic mollusc communities. Journal of Applied Ecology 43(3), pp. 474484, 2006.

[8] Lopez G. R. \& Holopainen, I. J. Interstitial suspension-feeding by Pisidium spp. (Pisidiidae: Bivalvia): A new guild in the lentic benthos? American Malacological Bulletin (5), pp. 21-30, 1987.

[9] Smit, H., Van Der Velden, J. A. \&. Klink. A., Macrozoobenthic assemblages in littoral sediments in the enclosed Rhine-Meuse Delta. Netherlands Journal of Aquatic Ecology 28(2), pp. 199-212, 1994.

[10] Yildız, S. \& Balık S., The Oligochaeta (Annelida) Fauna of the Inland Waters in the Lake District (Turkey), E.U. Journal of Fisheries and Aquatic Science, (22), pp. 165-172, 2005.

[11] Milbrink, G. Timm T. \& Lundberg S., Indicative profundal oligochaete assemblages in selected small Swedish lakes, Hydrobiologia, (468), pp. 53$61,2002$.

[12] Weatherhead, M.A., James, M.R., Distribution of macroinvertebrates in relation to physical and biological variables in the littoral zone of nine New Zealand lakes. Hydrobiologia (462), pp. 115-129, 2001.

[13] Bänziger, R., A comparative study of the zoobenthos of eight land-water interfaces (Lake of Geneva), Hydrobiologia (300/301), pp. 133-140, 1995.

[14] Cogerino, L., Cellot, B., Bournaud, M., Microhabitat diversity and associated macroinvertebrates in aquatics banks of large European river. Hydrobiologia (304), pp.103-115, 1995. 